
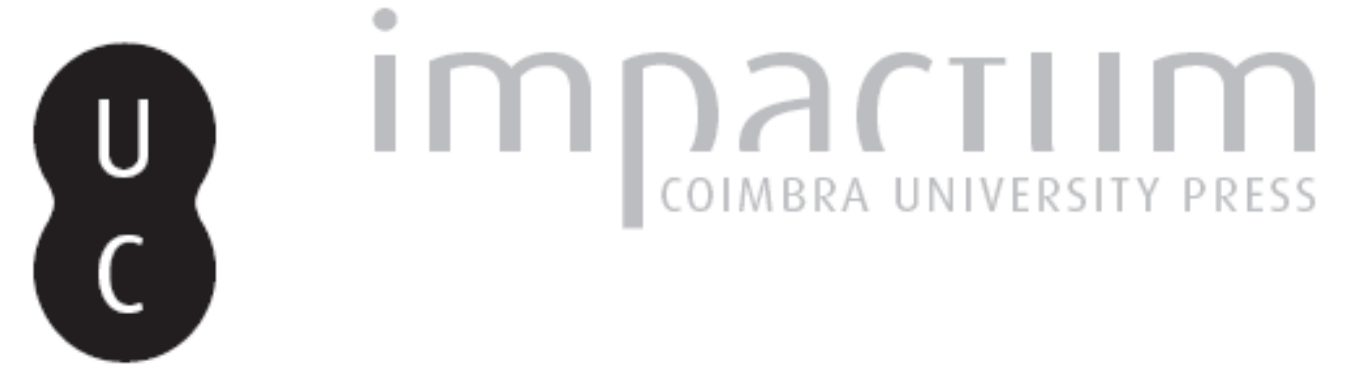

\title{
O final da Idade do Bronze e os inícios da Idade do Ferro no Ribatejo Norte (Centro de Portugal): uma breve síntese dos dados arqueográficos
}
Autor(es):
Félix, Paulo
Publicado por: Faculdade de Letras da Universidade de Coimbra
URL
persistente:
URI:http://hdl.handle.net/10316.2/37722
DOI:
DOI:http://dx.doi.org/10.14195/1647-8657_45_5
Accessed : $\quad$ 26-Apr-2023 06:57:16

A navegação consulta e descarregamento dos títulos inseridos nas Bibliotecas Digitais UC Digitalis, UC Pombalina e UC Impactum, pressupõem a aceitação plena e sem reservas dos Termos e Condições de Uso destas Bibliotecas Digitais, disponíveis em https://digitalis.uc.pt/pt-pt/termos.

Conforme exposto nos referidos Termos e Condições de Uso, o descarregamento de títulos de acesso restrito requer uma licença válida de autorização devendo o utilizador aceder ao(s) documento(s) a partir de um endereço de IP da instituição detentora da supramencionada licença.

Ao utilizador é apenas permitido o descarregamento para uso pessoal, pelo que o emprego do(s) título(s) descarregado(s) para outro fim, designadamente comercial, carece de autorização do respetivo autor ou editor da obra.

Na medida em que todas as obras da UC Digitalis se encontram protegidas pelo Código do Direito de Autor e Direitos Conexos e demais legislação aplicável, toda a cópia, parcial ou total, deste documento, nos casos em que é legalmente admitida, deverá conter ou fazer-se acompanhar por este aviso.

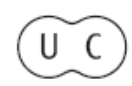




\section{CONIMBRIGA}

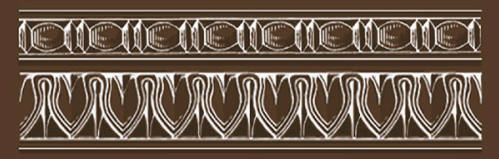

INSTITUTO DE ARQUEOLOGIA

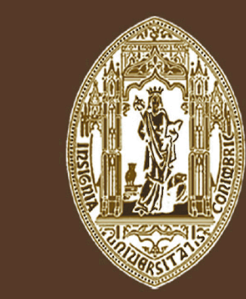

VOLUME XLV - 2006

FACULDADE DE LETRAS UNIVERSIDADE DE COIMBRA 


\section{PAUlo FÉliX}

Departamento de Pré-História e Arqueologia, Universidade de Granada Bolseiro da Fundação para a Ciência e a Tecnologia

O FINAL DA IDADE DO BRONZE E OS INÍCIOS DA IDADE DO FERRO NO RIBATEJO NORTE (CENTRO DE PORTUGAL):

UMA BREVE SÍNTESE DOS DADOS ARQUEOGRÁFICOS

"Conimbriga" XLV (2006) p. 65-92

Resumo: Apresenta-se uma síntese da investigação que desenvolvemos desde 1993 no Ribatejo Norte, região de transição entre o Tejo e o Mondego e entre o litoral e o interior, investigação centrada na reconstrução dos processos históricos que caracterizariam o final da Idade do Bronze e os inícios da Idade do Ferro.

ABSTRACT: We present in this paper a summary from the results of a research program under development since 1993 in Northern Ribatejo, a region in the centre of Portugal that is a path between different geographic settings, a research program centered in the assessment and reconstruction of the historical processes which would characterize the end of the Bronze Age and the beginning of the Iron Age. 
(Página deixada propositadamente em branco) 


\section{O FINAL DA IDADE DO BRONZE E OS INÍCIOS DA IDADE DO FERRO NO RIBATEJO NORTE (CENTRO DE PORTUGAL): UMA BREVE SÍNTESE DOS DADOS ARQUEOGRÁFICOS ${ }^{1}$}

\section{Notas iniciais}

Este artigo recolhe um conjunto de informações recuperadas através do desenvolvimento de um programa de investigação dos processos históricos ocorridos numa região concreta do centro-oeste de Portugal - que designaremos, de aqui em diante, Ribatejo Norte -, durante um período temporal que corresponde, na terminologia arqueológica convencional, ao Bronze Final e aos inícios da Idade do Ferro. Em cronologia de anos de calendário, equivale ao período compreendido entre os inícios da segunda metade do segundo milénio antes da nossa era e os inícios do segundo quartel do milénio seguinte. $\mathrm{O}$ que agora se apresenta constitui um reflexo ainda muito preliminar de um projecto desenvolvido desde 1993 que culminará, muito em breve, na dissertação de doutoramento que preparamos para leitura no Departamento de Pré-História e Arqueologia da Universidade de Granada (Espanha) ${ }^{2}$.

1 Agradecemos as sugestões e críticas formuladas por Pedro Aguayo, Raquel Vilaça, Ana Margarida Arruda, Andrés Adroher e Maria José de Almeida. De qualquer forma, as opiniões aqui expressas são estritamente pessoais, não representando necessariamente a linha de pensamento daqueles que contribuíram para o enriquecimento deste trabalho.

2 O programa de investigação integrou os seguintes projectos: "Caracterização Sócio-económica das Comunidades da Primeira Metade do Primeiro Milénio AC na Região Nabantina" (1993-1997) e "O Final da Idade do Bronze e a Transição para a Idade do Ferro no Ribatejo Norte” (1998-2001), este último financiado pelo Instituto 
A investigação arqueológica realizada no Ribatejo Norte nos últimos 25 anos conduziu à recuperação de uma informação muito importante, tendo em vista a reconstrução dos processos históricos de períodos tão díspares como o Paleolítico Antigo ou a Romanização. No entanto, e apesar do nível quantitativo e qualitativo dos projectos que se desenvolveram, os dados referentes ao final da Idade do Bronze e aos inícios da Idade do Ferro surgiram quase sempre como expressões residuais de programas cujos propósitos fundamentais não contemplavam a sua inventariação e estudo sistemático.

Diante de um panorama como o que se nos apresentava, iniciámos a tarefa de sistematização da informação existente. Ao mesmo tempo, principiámos a busca de novos registos que pudessem contribuir para uma resposta mais controlada e objectiva a toda uma série de questões que nos pareciam essenciais para o desenvolvimento de um programa de estudos coerente e ancorado no objectivo de reconstrução de um processo histórico concreto, segundo uma metodologia e um conjunto de premissas sustentadas pelo corpo teórico geral do Materialismo Histórico.

\section{Os finais da Idade do Bronze e a transição para a Idade do Ferro no Ribatejo Norte: algumas notas (provisórias) sobre o registo investigado}

A amostra com que contamos neste momento consta de um pouco mais de meia centena de registos, entre contextos de habitat, possíveis contextos funerários e achados isolados datados entre o Bronze Pleno e os inícios da Idade do Ferro. Saliente-se contudo que alguns destes registos não estão isentos de dificuldades de interpretação conveniente, seja porque a sua cronologia não se encontra ainda perfeitamente estabelecida, seja porque a sua funcionalidade é bastante discutível. Neste estudo apresentaremos apenas aqueles contextos que foram objecto de intervenções da nossa responsabilidade no âmbito dos projectos

Português de Arqueologia ao abrigo do Plano Nacional de Trabalhos Arqueológicos 1998. O autor beneficia igualmente de uma bolsa de formação avançada concedida pela Fundação para a Ciência e a Tecnologia para o período 2003-2006.

Conimbriga, 45 (2006) 65-92 
de investigação que dirigimos entre 1993 e 2001 (fig. 1), embora o registo seja muito mais vasto (Félix 2004).

\subsection{Serra de Alvaiázere (Alvaiázere, Leiria)}

\subsubsection{Introdução e enquadramento geográfico}

O povoado fortificado da Serra de Alvaiázere foi pela primeira vez referido na literatura arqueológica pela mão de José Leite de Vasconcellos $(1917,147)$, assinalando apenas a presença, no topo da serra que lhe dá o nome, de uma "rude muralha", sem mencionar qualquer outro tipo de estruturas ou materiais. Se bem que a região de Alvaiázere se venha a tornar bastante conhecida no meio arqueológico como uma das mais ricas em achados de artefactos metálicos da Idade do Bronze (cf., por exemplo, Coffyn 1985), a existência de um local de povoamento atribuível ao Bronze Final não será plenamente confirmada antes de iniciada a década de 1990 (Félix 1999). As nossas escavações realizaram-se em 1997, 2000 e 2001, incidindo em apenas um sector de reduzidas dimensões, consideradas face à extensão do contexto.

Desde que começámos a visitar com regularidade a serra de Alvaiázere que nos deparámos com uma característica que nos surpreendeu enormemente: o tamanho "anormal" do povoado. Partindo do princípio que os derrubes que circundam praticamente toda a área mais elevada da serra, com cerca de 3300 metros de perímetro, são os restos de uma estrutura de fortificação ou de delimitação espacial datável dos finais da Idade do Bronze, isso prefigura uma superfície total contida de mais de 50 hectares, dimensões fora do que constitui a regra nos contextos desta época à escala peninsular (fig. 2). Acreditou-se durante algum tempo que o que viemos a denominar de muralha exterior tivesse sido edificado em época muito posterior, mas toda uma série de factores concorreram para que se tornasse mais consistente a nossa actual interpretação: o sistema de construção, a existência de numerosas plataformas com 5-10 metros de largura, e bastante mais de comprimento, ao longo das vertentes oeste e leste da serra, limitadas pela referida "muralha" , e a homogeneidade

3 Durante uma das nossa primeiras visitas tivemos a oportunidade de verificar a existência de bastantes fragmentos de cerâmica de tipologias afins das comuns do

Conimbriga, 45 (2006) 65-92 
geral dos elementos de cultura material recolhidos durante as diversas prospecções realizadas, que apontavam seguramente para uma cronologia dentro da última fase da Idade do Bronze.

No extremo norte da serra existe uma segunda cintura murada, encostada à escarpa oriental, sobressaindo da cota geral do terreno apenas cerca de 0,5 metros, em média. Possui uma delineação subcircular com 368 metros de perímetro, uma área algo superior ao hectare e duas entradas abertas em lados opostos, uma possibilitando o acesso a partir do norte, a outra pelo sul. Foi identificada com o termo estrutura circular.

Este sítio arqueológico integra-se geograficamente no vale superior do rio Nabão, localizando-se no topo da serra da qual recebe a sua designação. A geologia local compõe-se de formações carbonatadas de idade jurássica, realçando-se a série de calcários compactos organógenos do Dogger (Jurássico médio) subsequentemente levantadas durante a orogenia alpina e afectadas por episódios de neo-tectónica (Cunha 1990, 283-291). Estes acontecimentos encontram-se particularmente bem representados através de diversas escarpas de falha, sendo bastante manifesta a que limita a serra pelo seu lado nascente, às vezes com mais de 50 metros de altura visível. Os quase 620 metros de máxima altitude da serra acentuam a diferença relativamente à paisagem adjacente, em regra mais de 200 metros abaixo.

\subsubsection{Estratigrafia e estruturas}

Devido a razões logísticas e financeiras, a primeira campanha de escavações limitou-se à abertura de um pequeno corte de teste estrati-

Bronze Final do ocidente da Península Ibérica nas paredes de um corte realizado numa das plataformas da vertente oriental, da responsabilidade de autor ou autores não identificados. Este corte, com uma delineação irregular, possuía cerca de quatro metros de comprimento e um pouco menos de dois metros de largura, atingindo, em alguns pontos, cerca de um metro de profundidade. Embora o corte não chegasse ao limite do derrube e não fosse possível observar qual a relação estratigráfica entre este e os sedimentos da plataforma, não nos ficaram nenhumas dúvidas de que os materiais cerâmicos incluídos no enchimento, pelas suas dimensões e quase ausência de desgaste, se encontravam contextualmente in situ. Infelizmente, não nos foi possível realizar uma intervenção imediata neste local e, no ano seguinte, essa zona foi totalmente coberta com uma camada de sedimentos avermelhados estranhos ao contexto, por forma a construir-se uma pista de lançamento de voos de parapente!

Conimbriga, 45 (2006) 65-92 
gráfico que pudesse proporcionar informação respeitante à questão que, nessa altura, considerávamos fundamental: determinar a sequência de ocupação. Deste modo, tendo em conta as dimensões do contexto, preferimos concentrar os nossos esforços na estrutura circular (Zona EC), abrindo-se um corte com $8 \mathrm{~m}^{2}$ que cobriu a muralha e parte dos espaços interior e exterior à mesma (corte EC/A). A primeira fase de escavação deste corte, ocorrida em 1997, permitiu determinar que a cintura amuralhada possuía cerca de três metros de largura e apenas 0,5 metros de altura conservada.

$\mathrm{Na}$ plataforma interior à muralha, debaixo do nível superficial (UE1), só se detectaram dois níveis de sedimentação: a UE11, constituída por derrubes da estrutura de fortificação, e a UE3, uma camada de acumulação pós-abandono. Estes níveis correlacionam-se com as UE12 e UE4, respectivamente, do espaço exterior.

Nas segunda e terceira campanhas, realizadas em 2000 e 2001, objectivámos a aquisição de dados de natureza mais extensiva, isto é, procurámos identificar outros vestígios estruturais para além da cintura amuralhada e o tipo de ocupação do espaço interno do recinto. Assim, ampliámos o corte EC/A, formando agora dois sectores: um de 14x6 metros, o segundo com 7x7 metros, totalizando $133 \mathrm{~m}^{2}$ de área escavada. Os resultados desta ampliação, no que diz respeito à estratigrafia e à detecção de outras estruturas que não a muralha, não proporcionaram nenhuma novidade: não foi possível discernir, entre uma disposição mais ou menos caótica de blocos de calcário de todos os tamanhos e os afloramentos da rocha do substrato, qualquer tipo de ordenamento ou de padrão que sugerisse a existência de estruturas de habitação, do mesmo modo que não se encontraram nem "buracos de poste", nem estruturas de combustão.

Na campanha de 2000 abriu-se um segundo corte (corte EC/B), localizado na entrada norte do recinto. Tratava-se de um rectângulo com 10x4 metros, dos quais somente se escavaram $35 \mathrm{~m}^{2}$. Depois da remoção da camada superficial (UE101), apareceu imediatamente uma estrutura que interpretamos, de momento, como um pavimento de acesso ao interior do espaço amuralhado (UE102). Este pavimento, de tipo calçada, formado por pequenos blocos e lajes de calcário, às vezes integrando também fragmentos de seixos de quartzito e de moinhos manuais, interrompe-se exactamente na saída, mas o seu limite interno não pôde ser definido. Se bem que o grau de destruição desta área não permita ter uma visão segura da configuração da entrada, esta 
parece estreitar-se na sua zona média e é possível que fosse complementada com um muro de compartimentação (UE106-107).

Uma terceira e última área de sondagem $($ corte $E C / C)$ foi aberta em 2001. Escavou-se um sector reduzido de 6x3 metros que forma o seguimento para o interior do recinto do primeiro bloco pertencente a EC/A. Esta intervenção confirmou os dados já conhecidos: depois de desmontada a primeira camada, o tipo de sedimentação era exactamente igual ao do corte EC/A, aparecendo o mesmo nível de acumulação pós-abandono e o lapiás de base.

\subsubsection{Os artefactos (Est. III)}

Os artefactos recolhidos no povoado da Serra de Alvaiázere podem ser divididos em cuatro grandes categorias de análise:

a. indústria lítica: integra todos os materiais líticos que possam ser classificados como indústria lítica, sejam talhados ou polidos, excluindo-se artefactos tais como "seixos polidores" ou "percutores"; devido à sua natureza intrínseca, todos os materiais em sílex consideram-se indústria lítica, mesmo quando se tratem apenas de lascas de preparação ou de afeiçoamento;

b. cerâmica doméstica: constituída por todos os materiais cerâmicos recolhidos na Serra de Alvaiázere, já que não existem cerâmicas industriais;

c. metais: inclui todos os artefactos metálicos e restos da actividade metalúrgica que possuam vestígios de metais ou de compostos metálicos (por exemplo, escórias);

d. outros materiais: incorpora todos os demais materiais não considerados nas categorias anteriores.

Foram recolhidos 9097 objectos durante a vigência dos projectos de investigação por nós dirigidos, dos quais 8990 em escavação. Tal como seria de esperar num contexto deste tipo, a cerâmica doméstica domina largamente $( \pm 85 \%)$, seguida da indústria lítica $( \pm 9 \%)$ e da categoria de outros materiais $( \pm 5 \%)$. A maior parte dos materiais procede do corte EC/A (86,97\%), enquanto que apenas $1,18 \%$ é originário das recolhas de superfície. Ainda que o corte $\mathrm{EC} / \mathrm{C}$ tenha fornecido somente 9,33\% dos materiais recolhidos, uma análise de distribuição de recolhas por volume de sedimentos escavados revela que as médias 
dos cortes EC/A e EC/C são estatisticamente idênticas - 237,95 e 235,83 peças $/ \mathrm{m}^{3}$, respectivamente -, demonstrando uma assinalável semelhança de constituição entre estas duas áreas de intervenção. Apenas o corte EC/B foge à regra, com 109,05 peças $/ \mathrm{m}^{3}$, o que não constitui nenhuma surpresa face à funcionalidade deduzida para a zona de implantação do corte, a de um corredor de entrada no recinto, pelo que não seria normal que aí se aglomerassem com facilidade os materiais rejeitados. Então, os materiais desta zona proviriam unicamente da acumulação pós-abandono.

A categoria indústria lítica é formada por 852 peças, sendo que um pouco mais de $95 \%$ foi elaborada em sílex e, desta, mais de $60 \%$ é constituída por peças classificáveis dentro da categoria tipológica geral dos subprodutos de talhe. Reconhecem-se três grandes momentos de produção para a indústria talhada sobre sílex, sendo o mais antigo também o que apresenta maior expressão quantitativa: Epipaleolítico, Neolítico Final/Calcolítico e Idade do Bronze ${ }^{4}$. O material tipologicamente atribuível à Idade do Bronze é incaracterístico, reduzindo-se a pouco mais de meia dezena de peças sobre lasca com entalhes ou denticulados.

Todo o repertório de elementos de cerâmica doméstica é constituído por exemplares que podem ser classificados dentro da tipologia geral das produções manuais. $\mathrm{O}$ exame macroscópico das fracturas e das superfícies de alguns fragmentos representativos dos diferentes grupos identificados revela o predomínio de cozeduras que promovem uma oxidação incompleta dos materiais utilizados na manufactura dos recipientes. Este facto aponta para a existência de um sistema de produção apoiado numa tecnologia simples, de base doméstica, cujo propósito raramente iria mais além do suprimento das necessidades de auto-consumo (van der Leeuw 1984) ${ }^{5}$.

4 Agradecemos a ajuda prestada por António Faustino de Carvalho na elaboração do estudo da indústria lítica talhada da Serra de Alvaiázere.

5 Encontra-se em desenvolvimento um programa de estudos arqueométricos de uma amostra representativa dos materiais cerâmicos do povoado da Serra de Alvaiázere, ao abrigo do protocolo de colaboração entre o Instituto Português de Arqueologia e o Instituto Tecnológico e Nuclear, que poderá, muito brevemente, proporcionar novos dados sobre o sistema de produção cerâmica dos finais da Idade do Bronze/inícios da Idade do Ferro nesta região. 
Os grupos de produtos já reconhecidos reduzem-se essencialmente a dois (Félix 1999, 69 e 2004, 104):

a. recipientes de cozinha e armazenamento (com eventual integração de algumas produções destinadas ao transporte de líquidos), comportando pastas de média ou baixa compacticidade, inclusões não plásticas de granulometria grosseira, mal calibradas, constituídas maioritariamente por grãos de quartzo, feldspato e mica, se bem que as inclusões carbonatadas e orgânicas não sejam raras, conferindo a estas pastas o tão característico aspecto de "cortiça"; as superfícies são geralmente alisadas, com frequência recorrendo à técnica do cepillado; é possível o reconhecimento, pelo menos ao nível macroscópico, de um pequeno subgrupo de recipientes com pastas e acabamentos mais cuidados, uma distinção baseada na observação de uma melhor selecção e mistura dos elementos não plásticos e de um acabamento superficial que utiliza, por vezes, a técnica do alisamento brunido;

b. o segundo grupo engloba a chamada "cerâmica fina", formada pelos recipientes que interpretamos como funcionalmente adscritos ao serviço de alimentos e bebidas e, eventualmente, ao transporte e conservação de líquidos, sendo caracterizados por pastas com inclusões de menor tamanho, melhor calibrados, e acabamentos em que predomina o uso da técnica do alisamento brunido.

As formas reconhecidas até ao momento não se afastam muito do que é comum nos diversos contextos do ocidente da Península Ibérica já conhecidos (Senna-Martínez 1993; Vilaça 1995; Gómez Toscano 1997; Pavón Soldevila 1998; Arruda 1999-2000). No grupo das produções mais grosseiras, encontramos morfologias com colos altos cilíndricos ou subcilíndricos, bordos ligeiramente salientes, algumas vezes comportando decorações impressas ou incisas nos lábios, perfis dos terços inferiores em tronco de cone, passando ao terço superior através de um ombro quase sempre arredondado e bases exclusivamente planas. As cerâmicas mais finas compreendem as mesmas delineações morfológicas genéricas, embora os recipientes sejam, regra geral, mais pequenos e comportem com muita frequência uma carena bem explícita colocada no terço superior do perfil da peça. As bases podem ser tanto planas como umbilicais. 
No entanto, encontram-se presentes outras morfologias que poderão datar de meados do segundo milénio antes da nossa era (Díaz-Andreu García 1994; Carreira 1996a e 1996b; Pavón Soldevila 1998), citando como exemplos algumas formas carenadas com paredes mais grossas, normalmente com superfícies não brunidas, um exemplar de "queijeira/coador" e vários fragmentos com decoração constituída por impressões ou incisões realizadas sobre cordão plástico aplicado sobre o ombro ou o perfil inferior dos recipientes. Estes materiais, em conjunto com as peças de indústria lítica sobre sílex adscritas à Idade do Bronze, poderão indiciar o início da ocupação da Serra de Alvaiázere em momentos algo anteriores ao que usualmente se considera o limite cronológico mais antigo para os contextos do Bronze Final da Ibéria ocidental. Os fragmentos que apresentam uma ou ambas as superfícies brunidas representam cerca de $16 \%$ do cômputo geral da cerâmica doméstica inventariada, enquanto que os exemplares com decoração totalizam pouco mais de $1 \%$, constituídos maioritariamente por fragmentos de bordo com impressões ou incisões no lábio. Destacamos a presença de um único fragmento de bojo com decoração de padrões geométricos brunidos.

Finalmente, no que diz respeito ao conjunto de materiais classificados como "Outros", para além de uma importante amostra de moinhos manuais de arenito ferruginoso e granito, de dezenas de lascas e seixos de quartzito que apresentam marcas de talhe compatíveis com uma utilização como martelos ou percutores e de alguns fragmentos de argila de revestimento de paredes, é relevante referir a exumação de alguns artefactos de bronze: um fragmento laminar que poderia ter pertencido a um recipiente ou ao alvado de uma ponta de lança, algumas argolas, um punção truncado e o arco completo de uma peça enquadrável na família das fíbulas de dupla mola (Ruiz Delgado 1989, 69-118; Ponte 2001, 125-143).

\subsection{Quinta da Pedreira (Abrantes, Santarém)}

\subsubsection{Introdução e enquadramento geográfico}

A zona arqueológica da Quinta da Pedreira foi registada pela primeira vez em 1982 por Álvaro Batista, residente em Rio de Moinhos e funcionário da Câmara Municipal de Abrantes, informando acerca 
da existência de um conjunto de sepulturas tardo-romanas e de diferentes tipos de artefactos, por ele datados desde o Paleolítico até à Idade do Ferro. As sepulturas foram parcialmente escavadas ainda na primeira metade da década de 1980 (Ferreira 1992) e, no inverno de 1993-94, por ocasião da construção do troço Atalaia-Abrantes da actual A23, Maria Ramalho exumaria uma série de estruturas de habitat próximas, igualmente datadas de época tardo-romana e visigótica (Félix 1997). Nos finais da década de 1980, a abertura de uma vala de drenagem para protecção de um olival permitiu a Álvaro Batista o reconhecimento de um alinhamento constituído por blocos de granito e quartzito e a recuperação de alguns materiais (cerâmica, indústria lítica, um fragmento de um machado de bronze e vários fragmentos de argila de revestimento com negativos de ramagens), materiais aos quais tivemos acesso em 1992, confirmando-se uma atribuição cronológica dentro do que convencionalmente se designa por Bronze Final. Uma subsequente visita ao sítio comprovou a existência de um local de povoamento consentâneo com a cronologia daqueles materiais, tratando-se, muito provavelmente, de um contexto que faria parte de um conjunto de unidades habitacionais de maior expressão (Félix 2004, 111) e não de uma "granja" ou "casal", como temos vindo a classificálo (Félix 1997) ${ }^{6}$.

A estação arqueológica da Quinta da Pedreira localiza-se na zona mais elevada de um terraço de idade pleistocénica da margem direita do rio Tejo, cerca de 40 metros acima do actual nível de águas no verão, a 62 metros de altitude. Nesta área, o terraço possui cerca de 100 metros de largura e foi parcialmente truncado pela A23. Por detrás da estação levanta-se uma série de elevações com 100-120 metros de altitude compostas por retalhos de terraços de idade pleistocénica mais antigos, depositados sobre conglomerados e arenitos do

6 A recuperação de bastantes materiais cerâmicos contemporâneos dos exumados na área das escavações um pouco por toda a plataforma e ao longo dos desaterros provocados pelas obras da A23, bem como a documentação (ainda que muito parcial) de restos de estruturas de combustão, faz-nos pensar que na Quinta da Pedreira existiu um núcleo de povoamento formado por várias unidades familiares, um contexto mais aproximado do de uma pequena aldeia do que de um "casal". Não obstante, como não foi possível ampliar a área de intervenção para além dos limites da zona escavada, esta interpretação encontra-se ainda afectada por bastantes debilidades e sujeita a confirmação futura.

Conimbriga, 45 (2006) 65-92 
Mioceno e do Plioceno (Barbosa 1995). Existem ainda alguns afloramentos graníticos nas proximidades, explorados como pedreiras pelo menos desde época romana.

\subsubsection{Estratigrafia e estruturas (Est. III)}

As sete campanhas de escavações realizadas entre 1994 e 2001 permitiram identificar uma estratigrafia complexa, descrita em mais de seis dezenas e meia de unidades de diferentes tipos, embora algumas dessas unidades correspondam a uma mesma matriz contextual: a multiplicação de unidades de descrição estratigráfica foi o resultado natural de uma metodologia que se desenvolveu em função da existência de descontinuidades entre as áreas escavadas e das dificuldades impostas pela própria constituição dos sedimentos.

Foi possível a individualização de dois momentos de ocupação na área intervencionada, ambos datando do Bronze Final, parcialmente sobrepostos, mas empregando idênticas soluções construtivas e de ordenamento do espaço: podem ser caracterizados formalmente como restos de duas construções de planta provavelmente elíptica, com alicerces formados por blocos de granito e seixos de quartzito e quartzo, sobre os quais se ergueriam paredes constituídas por um entrançado de materiais vegetais revestido a argila, apoiadas numa série de postes de madeira. Estas construções encontrar-se-iam rodeadas por uma "estrutura de contenção" de tipo "rampa de regularização" com cerca de dois metros de largura, feita com seixos de quartzito e quartzo, restos de moinhos manuais, fragmentos cerâmicos, nódulos de argila de revestimento e outros materiais rejeitados, tudo envolvido por uma matriz sedimentar silto-argilosa (esta estrutura serviria simultaneamente para suster as terras que circundavam as construções, que se situavam num nível inferior ao da superfície topográfica existente na época, e para escoar as águas pluviais para o exterior da zona habitada). É provável que estas "estruturas de contenção" estivessem circunscritas por um pequeno muro de seixos de quartzito.

Apesar de toda a destruição originada pela abertura da vala de drenagem, pudemos detectar uma lareira externa, que se associava sem qualquer tipo de dúvida à construção mais recente, formada por argila, fragmentos de cerâmica e seixos de quartzito, com cerca de 
dois metros de diâmetro por 20 centímetros de espessura. Esta lareira sobrepunha-se a uma outra, de menor tamanho mas muito bem estruturada em forma de círculo com pouco menos de um metro de diâmetro, delimitada por seixos de quartzito e contendo no seu interior uma camada de fragmentos de cerâmica coberta por uma camada de argila. A sua contextualização estratigráfica não é muito clara, embora pensemos que se pudesse relacionar com o primeiro momento de ocupação.

Para leste, a poucos metros desta área de intervenção, a concentração de alguns artefactos "especiais", concretamente um fragmento de um machado de bronze (recolhido por Álvaro Batista nos anos 1980), uma tubeira de forno de fundição, em argila, um seixo de quartzito com sinais de ter sido utilizado como martelo/percutor e dúzias de nódulos de argila queimada, sugere-nos a presença próxima de um contexto metalúrgico que, infelizmente, não foi possível investigar mais aprofundadamente.

\subsubsection{Os artefactos (Est. IV)}

Os materiais recolhidos entre 1994 e 2001, totalizando cerca de 3500 peças, compõem-se, em pouco menos de $80 \%$, de fragmentos de cerâmica de uso doméstico, dos quais apenas $7 \%$ não são atribuíveis às ocupações do final da Idade do Bronze. Dos fragmentos de cerâmica de época pré-histórica, os que mostram superfícies brunidas representam menos de 5\% do repertório contabilizado, uma proporção muito inferior à recuperada, por exemplo, na Serra de Alvaiázere (superior a 16\%), indicando que, neste contexto particular e dadas umas condições de investigação que apenas permitiram a recuperação de uma ínfima amostra do registo conservado, a utilização da técnica de acabamento por alisamento brunido foi muito excepcional, aplicada a um número muito reduzido de recipientes com uma presumível utilidade como "louça de mesa" ou destinados a cumprir uma função não estritamente mundana (Vilaça 1995, 290).

O estudo sistemático do repertório cerâmico exumado na Quinta da Pedreira, executado através do recurso a uma metodologia que reúne as contribuições dos procedimentos analítico-tipológicos tradicionais e da arqueometria ao serviço da caracterização tecnológica deste sistema de produção, autoriza-nos a propor a existência de ape- 
nas dois grupos principais de recipientes, apresentando um elevado grau de correlação entre a tecnologia de produção e a funcionalidade (Coroado et al. 2001 e 2004), não se diferenciando muito, neste aspecto, do deduzido para o povoado da Serra de Alvaiázere (cf. supra), exceptuando o facto de não existirem na Quinta da Pedreira pastas elaboradas com inclusões carbonatadas.

No capítulo das formas identificadas, apesar de ser possível o reconhecimento de algumas diferenças de pormenor relativamente àquele sítio do vale do Nabão, a série da Quinta da Pedreira segue de perto o padrão geral das morfologias nos contextos dos finais da Idade do Bronze do ocidente da Península Ibérica, predominando largamente as formas de tipo "pote" de médio e grande tamanho sobre os pequenos "potes" e as formas carenadas: entre estas, domina o "vaso carenado" sobre a "taça carenada". Registe-se ainda a presença de dois exemplares de forma esférica, uma morfologia que, embora rara, quase nunca está ausente dos contextos desta época (Senna-Martínez 1993; Vilaça 1995; Pavón Soldevila 1998). A decoração foi registada em apenas 26 fragmentos (1\% do total de fragmentos de cerâmica do Bronze Final), dos quais 23 são bordos com lábios decorados (18 com impressão digitada e cinco com incisões); os restantes pertencem a um único recipiente carenado e apresentam decoração brunida geométrica colocada numa faixa estreita na zona de transição entre a parede e a base.

Os restantes materiais compõem-se de alguns fragmentos de cerâmicas de construção de época romana, recolhidos apenas nos níveis superficiais da estação, umas dezenas de peças líticas de cronologia anterior à ocupação do Bronze Final e, contemporâneos desta ocupação, algumas centenas de nódulos de argila de revestimento, muitos apresentando negativos de ramagens e um exemplar ostentando restos de uma cobertura de cor branca na face plana, que poderá tratar-se de uma eventual pintura, alguns fragmentos de moinhos manuais e outros artefactos, dos quais destacamos duas peças associáveis a um provável contexto metalúrgico: uma tubeira de forno de fundição e parte de um molde para produção de um objecto não identificado. 


\subsection{Castelo da Cabeça das Mós (Sardoal, Santarém)}

\subsubsection{Introdução e enquadramento geográfico}

A estação arqueológica conhecida como Castelo, nas imediações da aldeia de Cabeça das Mós, foi identificada por Álvaro Batista na década de 1980, sumariamente publicada nos finais da década seguinte (Batata et al. 1999) e por nós escavada em 1999. Este contexto foi dividido em várias zonas, sendo as mais importantes as zonas designadas como "Cabeço Norte" (Zona $C N$ ), onde se realizaram as intervenções, "Cabeço Sul” (Zona $C S$ ), com materiais que apontam para a existência de um contexto de época romana, e "Entre Cabeços" (Zona EC), provavelmente, tendo em conta a grande quantidade de materiais recuperados em superfície, uma área de expansão do povoamento nuclear ainda durante a primeira fase da Idade do Ferro. Essa área "nuclear" situa-se na Zona CN, um espaço com uma configuração mais ou menos rectangular rodeado por uma linha de muralha já bastante mal conservada.

O povoado localiza-se na confluência entre as ribeiras de Arcês e do Travesso, no limite administrativo entre os concelhos do Sardoal, de Abrantes e de Mação, sendo a geologia local constituída por gnaisses, micaxistos, xistos argilosos e grauvaques do Pré-câmbrico; os solos são normalmente litólicos, pouco húmicos e ácidos, suportando uma cobertura vegetal dos tipos bem adaptados a condições edáficas difíceis.

\subsubsection{Estratigrafia e estruturas (Est. V)}

Como já antes dissemos, a intervenção arqueológica no Castelo da Cabeça das Mós restringiu-se à Zona $\mathrm{CN}$, com a abertura de três cortes de sondagem. O corte CN/A localizou-se na área mais elevada do cabeço, cerca de três metros abaixo da sua cota mais alta, próximo da secção sul da linha de muralha. Os $18 \mathrm{~m}^{2}$ intervencionados revelaram uma estratigrafia muito simples, descrita em apenas cinco unidades estratigráficas, das quais realçamos a UE3, constituindo os restos dos alicerces de uma estrutura de planta circular com cerca de dez metros de diâmetro, formados por uma série de blocos de pequenas dimensões de gnaiss assentes directamente sobre o substrato 
rochoso. A recuperação de mais de sete dezenas de fragmentos de argila de revestimento com as características marcas de entrançado vegetal parece reforçar a interpretação que fazemos deste sector como contexto habitacional.

Junto da secção norte da linha defensiva abriu-se o corte CN/B, do qual se escavaram $48 \mathrm{~m}^{2}$. A sequência estratigráfica foi descrita em 12 unidades, dez delas exclusivas deste espaço. As estruturas registadas incluem a referida linha defensiva (UE112-113), dois muros com desenvolvimento curvilíneo (UE103 e UE106) e respectivos derrubes (UE104-105 e UE107-108) e os alicerces de uma construção de planta poligonal com ângulos (UE110). O sistema de elaboração e as relações estratigráficas desta estrutura com respeito às restantes fazem-nos crer que se trata de uma "intrusão" bastante posterior ao abandono do povoado da Idade do Ferro, muito provavelmente de época medieval ou moderna. As demais estruturas construídas observam o que constitui "norma" para as edificações da Idade do Ferro: um sistema de blocos com tamanhos médios, grosseiramente afeiçoados, colocados com a técnica da "pedra seca" (ou, quando muito, utilizando uma simples argamassa de argila), blocos que definem dois pequenos muros com desenvolvimento mais ou menos curvilíneo, ainda que o grau de destruição apresentado nos dificulte sobremaneira a sua interpretação (contexto habitacional com espaços anexos?).

Finalmente, o corte $\mathrm{CN} / \mathrm{C}$ implantou-se entre os dois anteriores, sensivelmente a meia-encosta, escavando-se $18 \mathrm{~m}^{2}$ que, no que concerne à sequência estratigráfica, se revelaram parcos em informação: a única estrutura (?) digna de nota nesta sequência foi a UE203, provisoriamente interpretada como uma "rampa de regularização".

\subsubsection{Os artefactos (Est. VI)}

O conjunto de artefactos recolhidos no Castelo da Cabeça das Mós é formado por escassa indústria lítica (uma lasca de quartzito, uma lasca de sílex com retoque denticulado e um "peso de rede/tear" de quartzito), fragmentos de moinhos manuais e rotativos, nódulos de argila de revestimento, alguns cossoiros de cerâmica (um deles decorado), contas de pedra, pasta vítrea, vidro e cerâmica, um objecto de ferro não identificado, escória de fundição do mesmo metal, fragmentos de cerâmica de construção de época romana e posterior e 
alguns milhares de fragmentos de cerâmica doméstica cobrindo o período compreendido entre o Bronze Final/Ferro Antigo e a Romanização.

Uma síntese não exaustiva do repertório de cerâmica doméstica permite a decomposição desta categoria de artefactos em recipientes de modelação manual com formas e acabamentos de "tradição" do Bronze Final (carenados com superfícies brunidas, potes com lábios decorados e um fragmento de vaso carenado com decoração brunida geométrica no colo), recipientes de modelação manual e ao torno com formas que correspondem a potes com colos pouco desenvolvidos e bordos muito salientes (existem alguns fragmentos que apresentam decoração estampilhada), recipientes modelados ao torno com pastas cinzentas ou alaranjadas e superfícies cinzentas brunidas, recipientes modelados ao torno com pastas alaranjadas e acabamentos alisados, alguns fragmentos de ânforas romanas alto-imperiais (Haltern $70 \mathrm{e}$ Almagro 51a-b) e de sigillata hispanica.

\section{Os finais da Idade do Bronze e a transição para a Idade do Ferro no Ribatejo Norte: algumas ideias (ainda em fase de desenvolvimento) sobre um processo histórico}

Um primeiro esboço de um modelo explicativo do processo histórico investigado no Ribatejo Norte, datado de entre meados do segundo milénio antes da nossa era e meados do milénio seguinte, foi apresentado há cerca de ano e meio (Félix 2004) e, desde essa data, já introduzimos, como seria de esperar, algumas alterações de pormenor, ainda que as linhas mestras do raciocínio se mantenham, nos seus contornos gerais, dentro dos mesmos parâmetros. Porque se reserva para mais tarde uma publicação detalhada deste modelo, pouco mais faremos aqui do que reiterar aquela proposta.

As formações sociais dos finais do segundo milénio antes da nossa era radicam as suas origens numa etapa ainda muito mal definida no contexto regional que nos importa (e, igualmente, em outros contextos ao nível peninsular), etapa que poderia equivaler ao que outros autores costumam designar como "Bronze Pleno" (por exemplo, Carreira 1996a e 1996b). Este eventual Bronze Pleno estaria relativamente bem representado em algumas das grutas da região 
(Almonda e Bugalheira) e, embora com ainda menos certezas, em uns poucos povoados de altura (por exemplo, Agroal, Serra de Alvaiázere e Moinho do Ferradouro). Os traços indicadores desta etapa seriam, acima de tudo, algumas cerâmicas de confecção mais "grosseira", quando comparadas com as suas correspondentes do Bronze Final, a localização da linha de carena num plano horizontal mais baixo relativamente ao que é "normal" no período seguinte, uma presença mais frequente de decorações digitadas ou incisas sobre cordão plástico, uma maior ocorrência de mamilos decorativos ou pegas mamilares em recipientes de grande tamanho e uma maior proporção de formas esféricas no conjunto do repertório vascular.

Na serra de Alvaiázere localiza-se um dos maiores contextos de povoamento dos finais da Idade do Bronze conhecidos na metade ocidental da Península Ibérica, constituído por duas linhas de muralha que definem aparentemente duas fases distintas de ocupação do espaço e, em concomitância, de controlo do território: na primeira fase, a área ocupada pelo povoado reduzir-se-ia a um espaço murado com pouco mais de um hectare de superfície, localizado na extremidade norte da serra; a partir de um momento que situamos cronologicamente no séc. VIII-VII antes da nossa era, a área habitada/ocupada ter-se-ia expandido até abarcar toda a metade setentrional da serra, delimitando-se esse espaço, igualmente, com uma estrutura amuralhada.

Na primeira fase, cujos inícios poderíamos colocar hipoteticamente em meados ou no terceiro quartel do segundo milénio antes da nossa era, teríamos um pequeno povoado murado, com cerca de um hectare de superfície, localizado numa zona da serra que privilegiaria o controlo imediato da circulação entre o vale do rio Nabão e a ampla depressão do "Campo de Alvaiázere", via natural de ligação para as terras meridionais. Na segunda fase, o controlo da depressão de Alvaiázere ver-se-ia ampliado através da incorporação da vigilância para oeste e para sul. Nesta primeira fase, reproduzir-se-ia um modelo de controlo estratégico do território em função da localização do povoado nas imediações das vias de trânsito e dos campos de cultivo, mas, por outro lado, conservando-se "escondida" a área de habitação (não é visível para quem se aproxime vindo do sul ou do oeste). Em contraponto, a segunda fase viria a ser caracterizada por uma apreciável transformação das estratégias de controlo territorial, sendo agora muito mais conspícua e compreendendo uma área de ocupação bas- 
tante mais extensa, pressupondo alterações radicais no sistema de organização sociopolítica e económica que conduziram a um processo de concentração populacional num único povoado, abandonando-se a totalidade ou a quase totalidade dos locais de habitat de menor entidade existentes na região.

Uma datação precisa para o enquadramento deste processo é, ainda, algo especulativa, mas cremos não estar muito distantes da realidade quando o fazemos depender da instalação prévia dos primeiros empórios fenício-orientalizantes nos estuários do Tejo e do Mondego, provavelmente a partir dos momentos finais do séc. VIII antes da nossa era ou dos inícios da centúria seguinte (Arruda 1999-2000).

Poderíamos ainda mencionar a possibilidade, pelo menos no plano teórico, de que estas transformações se tivessem produzido apenas devido a factores intrínsecos, à dinâmica própria das formações sociais do final da Idade do Bronze desta região, sem depender da introdução de variáveis externas impostas e/ou aceites por aquelas, resultando da evolução interna de um sistema sociopolítico e económico basicamente autárquico e auto-suficiente ou, quando muito, com ligações de dependência política bastante flexíveis (Vilaça 1995, 412), em direcção a uma organização fortemente centralizada e hierarquizada, ainda antes da instalação dos empórios fenício-orientalizantes em território peninsular ocidental. Contudo, não encontramos razões lógicas plausíveis para que se produzisse esse processo de concentração populacional e centralização política, e para que se justificassem os custos políticos que o desenvolvimento e consolidação de tal processo inevitavelmente suscitariam, sem que houvesse a montante uma motivação muito forte que impulsionasse o rompimento dos tradicionais laços de solidariedade consanguínea e compensasse as perdas que a emergência de um sistema de relações sociais mais "impessoais" e teoricamente mais desiguais causaria aos segmentos detentores do poder, tendo em consideração um esperado aumento das contradições sociais e da resistência à transformação por parte dos segmentos sociais desfavorecidos.

No contexto específico que estudamos, essa motivação dificilmente poderia ser outra que a constatação dos enormes benefícios que uma reestruturação do sistema sociopolítico e económico aportaria àqueles segmentos das formações sociais indígenas que detinham o poder, uma reestruturação instigada nos "bastidores" pelos comer- 
ciantes fenício-orientalizantes. A estes, interessava-lhes fomentar a intensificação das actividades económicas, tendo como objectivo incrementar a exploração dos recursos locais, o que só seria possível, segundo uma lógica económica de mercado alheia a formações sociais com sistemas económicos não mercantis, com a transformação das estruturas de relações sociais dos grupos explorados. Um objectivo que poderia ser atingido através da conquista dos territórios indígenas por meios militares, hipótese que parece não ser aceitável para o contexto do ocidente peninsular, nem mesmo para o conjunto da Península Ibérica. Em alternativa, esse objectivo também podia ser conseguido induzindo a transformação dos sistemas de organização sociopolítica e económica indígenas a partir da próprias estruturas ideológicas e políticas internas dos grupos locais, uma estratégia inerente a um esquema de interacções de raiz colonialista, em que, pelo menos num momento inicial, o grupo colonial "adquire" os favores das elites políticas indígenas, a troco de uma participação destas nos benefícios da exploração económica que vai ser estabelecida.

Os mecanismos que foram utilizados pelos segmentos dirigentes das formações sociais indígenas para a consecução do processo de concentração populacional e de fortalecimento do seu poder político e da consequente transformação do conjunto das estruturas sociais e económicas, não são de fácil reconstituição. No entanto, pensamos que deveriam envolver dispositivos tais como a manipulação ideológica e a coerção física, não se colocando de lado, em alguns casos, o uso de instrumentos extremos de dominação, como a ameaça de exílio, a escravatura e, inclusive, a execução dos resistentes à transformação.

A reestruturação do sistema de organização social global das formações sociais do final da Idade do Bronze na região centro-ocidental da Península Ibérica nos alvores da Idade do Ferro, inaugurados os processos de interacção desigual com o mundo fenício-orientalizante, também é visível em outros âmbitos que não a área de Alvaiázere. No estuário do rio Mondego, a fundação do entreposto de Santa Olaia teve como consequência quase imediata a criação de um grande povoado indígena nas suas proximidades (o castro de Tavarede) e a multiplicação de contextos de povoamento de tipo "casal" destinados à exploração intensiva dos férteis terrenos agrícolas presentes na região, sobretudo na margem direita do rio. O povoado de Conímbriga também deverá ter crescido em tamanho, concentrando a população da sua área de influência (a margem esquerda do Mondego), se bem que, 
aqui, os vestígios materiais imputáveis a esta fase sejam muito parcos, devido, nomeadamente, aos intensos fenómenos de perturbação provocados pela continuidade da ocupação do sítio até época tardo-romana. Não obstante, a recuperação de uma quantidade muito apreciável de materiais de filiação fenícia ou fenício-orientalizante (Arruda 1999-2000, 247-249) sugere-nos que o povoado de Conímbriga manteve ou, inclusive, viu aumentada a sua importância como centro económico e político regional durante a Idade do Ferro antiga. Ana Margarida Arruda (Ibid., 253) coloca a hipótese de que as populações que ocuparam a margem direita do estuário, edificando o castro de Tavarede e as várias unidades de exploração de tipo "casal”, tivessem vindo de Conímbriga. Pelo contrário, tendo em consideração os indícios de crescimento observado neste sítio da margem esquerda, opinamos que os locais mais prováveis para a origem dos contingentes que povoaram Tavarede e os "casais" da margem direita do estuário do Mondego (Pereira 1993-94) se localizariam em outros âmbitos, embora não excluamos liminarmente algum tipo de contribuição vinda do território de Conímbriga.

Um pouco mais ao sul, junto do Tejo, escavámos durante vários anos um contexto que, numa primeira análise, poderia considerar-se como um bom exemplo da tipologia "casal agrícola", definida, há já alguns anos, por Marques e Andrade (1974). No entanto, as informações que pudemos recolher enquanto as máquinas removiam as terras para a construção da A23, autorizam-nos uma interpretação da Quinta da Pedreira mais como pequeno povoado que como unidade unifamiliar de exploração agrícola. Este sítio arqueológico, qualquer que seja a sua tipologia concreta, fazia parte de um sistema de organização territorial que incluía outros locais funcional e estruturalmente análogos, que estariam, por seu turno, dependentes do grande povoado da Fortaleza de Abrantes, localizado numa colina proeminente que domina directamente a comunicação este-oeste, segundo o curso do Tejo, e o acesso às terras ricas em minerais do interior, em direcção norte. Os materiais que se recuperaram acidentalmente nuns derrubes da base do lanço oriental da muralha da fortificação setecentista, em conjunto com alguns dados ainda não confirmados acerca do aparecimento de cerâmicas do Bronze Final numas escavações realizadas há anos no interior da fortaleza (Bübner 1996, 69), levam-nos a pensar que aqui se localizou, nos finais da Idade do Bronze, um importante local aglutinador da exploração de um amplo território, um local que, muito 
provavelmente, orientou o processo de intensificação económica e de centralização política do mesmo modo que o fizeram Conímbriga, Tavarede ou Alvaiázere.

Porém, ainda não estamos em condições de assegurar qual o modelo concreto adoptado nesta área do vale do Tejo. No caso da Serra de Alvaiázere, a população concentrou-se num único povoado e a razão de ser deste facto parece-nos clara: conseguir o máximo rendimento de algumas centenas de hectares de terras férteis imediatamente disponíveis no "Campo de Alvaiázere". Para Conímbriga, onde esses terrenos não se encontram tão próximos, sugerimos a adopção de um modelo de disseminação de "casais" pelas terras baixas da margem esquerda do estuário do Mondego, um esquema reproduzido na margem direita e centrado no castro de Tavarede.

Não existe, na região de Abrantes, nenhum dado que nos aponte a presença de contextos de tipo "casal" ou "povoado aberto de vale" com uma cronologia posterior ao Bronze Final sensu stricto. Salientese que esta é uma impressão deduzida, como é evidente, a partir da análise dos elementos de cultura material que foram recuperados até à data. Podemos apontar duas hipóteses de explicação deste facto: a primeira postularia que os "casais" e/ou pequenas aldeias de vale se desocupam realmente durante a etapa terminal do Bronze Final e que a população deste domínio territorial se concentra na Fortaleza de Abrantes e, eventualmente, no Castelo da Cabeça das Mós, cuja fundação nos parece poder ser reportada a esta época; a alternativa estipularia que aqueles contextos de vale continuariam a funcionar durante a Idade do Ferro antiga, não sendo esta fase detectável na cultura material porque não existe uma transformação apreciável da mesma, devido, antes de tudo, à impossibilidade de acesso destas populações aos novos produtos. Pesando os prós e contras de ambas as hipóteses, inclinamo-nos decididamente pela primeira, já que em todos os demais âmbitos regionais em se detectou um sistema de povoamento disseminado e diversificado durante a Idade do Ferro antiga (Pereira 1993-94; Cardoso 1995; Arruda 1999-2000), se apreciam alterações importantes ao nível da composição do conjunto da cultura material, com a introdução de produtos que não fazem parte do repertório característico do Bronze Final7.

7 Contudo, esta constatação não significa que não consideremos a plausibilidade de um modelo que estabeleça a continuidade do sistema de povoamento "misto" dos 
Esta dúvida também afecta a reconstituição do que se passou no âmbito territorial de Santarém. Aqui, o modelo poderia ser o seguinte: a existência de um importante povoado do Bronze Final situado na área da Alcáçova, com indícios de uma rede de pequenos povoados e/ou "casais" na margem esquerda do rio, provavelmente dependentes do "centro" instalado em Santarém, e, a partir do estabelecimento de um eventual empório fenício-orientalizante neste povoado, desaparecimento daqueles contextos da margem esquerda e crescimento de Santarém. Existem, porém, diversos problemas de documentação que tornam muito difícil optar por um modelo definitivo, sendo um dos mais cruciais saber se houve realmente na Alcáçova de Santarém uma ocupação de Bronze Final "pré-colonial” e, em caso afirmativo, qual a sua importância relativa no conjunto do sistema de povoamento desta região. As escavações realizadas por Ana Margarida Arruda e colaboradores ao longo de bastantes anos na zona da Alcáçova e em outros pontos da cidade, apenas permitiram a recuperação de testemunhos que se inserem na Idade do Ferro antiga, reafirmados por duas datações de ${ }^{14} \mathrm{C}$ que colocam este momento grosseiramente entre meados do séc. X e meados do séc. VIII antes da nossa era (Arruda 1999-2000, 217-218) ${ }^{8}$. Ainda que todos os dados pareçam indicar uma fundação de Scallabis já em época contemporânea da presença fenício-orientalizante no estuário do Tejo, existem indícios, embora diminutos, que favorecem a hipótese que defende a ocupação humana

finais da Idade do Bronze até momentos mais tardios dentro do primeiro milénio antes da nossa era; as ferramentas analíticas que utilizamos não nos permitem discernir com clareza quando e como se produzem as interfaces de ruptura entre modos de produção diferentes e, por conseguinte, são incapazes de decompor as complexidades inerentes a estes episódios de transição. Assim sendo, o que nos é apresentado como uma unidade discreta, com todos os seus descritores bem definidos e temporalmente balizados, pode muito bem ter possuído uma "continuidade" histórica arqueologicamente não identificável nem demonstrável, levando-nos a realizar interpretações ofuscadas por uma aparente realidade.

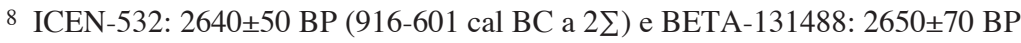

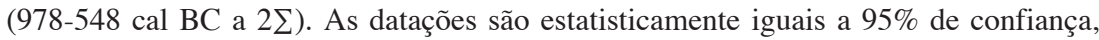
podendo combinar-se para a obtenção de uma única data de 971-555 cal BC a $2 \Sigma$, caindo o intervalo de maior probabilidade $(91,9 \%)$ em 936-747 cal BC. Calibração realizada com o programa informático CALIB (Stuiver e Reimer 1993, versão 5.0), referente à curva IntCal04 (Reimer et al. 2004).

Conimbriga, 45 (2006) 65-92 
da colina da Alcáçova de Santarém já desde a fase terminal da Idade do Bronze (Ibid., 223; Vilaça e Arruda 2004, 33).

A inexistência ou, pelo menos, a insuficiência de vestígios seguros de ocupações atribuíveis à Idade do Ferro sensu stricto na margem esquerda do Tejo ${ }^{9}$, sugere-nos que esta área deixou de ser utilizada de modo intensivo nesta fase, talvez porque não se justificassem os custos de manutenção de núcleos de povoamento face, possivelmente, a uma menor disponibilidade de terras agrícolas de qualidade ${ }^{10}$, ou porque esses terrenos poderiam ser perfeitamente trabalhados e controlados a partir das populações estabelecidas na margem direita ou, ainda, porque esses terrenos foram, pura e simplesmente, abandonados, concentrando-se todo o sistema produtivo na outra margem. A não ser que tivessem continuado em funcionamento os antigos contextos do Bronze Final, sem que se apreciasse qualquer transformação que pudesse vir a ser detectada pela Arqueologia.

Concentração de toda uma população num único e grande povoado, manutenção das estratégias anteriores de exploração do território ou transferência de parte da população de um ou vários âmbitos, todos constituem modelos diversos de uma mesma classe de transformação sociopolítica e económica. Referimo-nos à que surgiu como resposta das elites indígenas às solicitações de uma potência que se instalou em pontos estratégicos das costas do quadrante sudoeste da Península Ibérica com o objectivo bem definido de explorar o máximo possível dos recursos minerais, agrícolas e pecuários que se encontravam nas mãos das formações sociais do Bronze Final. Esta transformação implicou necessariamente numa centralização crescente do poder e numa reestruturação do sistema de relações interpes-

9 Uma suposta datação dentro da Idade do Ferro atribuída, ainda que sem muita convicção, ao Alto do Castelo, no concelho de Alpiarça (Kalb e Höck 1988), já não é possível defender-se na actualidade, o que nos deixa, na prática, sem qualquer referência a núcleos de povoamento desta época na margem esquerda do Tejo, na área de Santarém. A única ocupação pré-histórica aparentemente comprovada no Alto do Castelo datar-se-ia dos finais da Idade do Bronze, uma ocupação que estaria associada à utilização das necrópoles de Tanchoal, Meijão e Cabeço da Bruxa (Vilaça, Cruz e Gonçalves 1999).

10 É necessário ter em consideração as alterações geomorfológicas ocorridas neste âmbito geográfico, implicando que as vastas extensões de lezíria que actualmente são visíveis não deveriam existir há 3000 anos atrás. 
soais que resultaram no aumento da desigualdade e da opressão sobre os segmentos menos favorecidos da população, envolvendo a utilização, por parte dos segmentos dirigentes, de instrumentos de coerção que obrigassem o grosso da população a aceitar as novas relações. As vantagens e os benefícios que as elites dirigentes indígenas divisaram com a integração num sistema de carácter colonial foram, decerto, muito maiores que os custos implicados no desmantelamento, ainda que parcial, das tradicionais estruturas de solidariedade consanguínea.

Não obstante, a nova estrutura de relações alicerçou-se sobre bases ainda muito frágeis. Desaparecida a pressão provocada pela manutenção de um sistema de benefícios sócio-económicos e políticos baseado em vínculos assimétricos com uma potência colonial, a partir de meados ou finais do séc. VI antes da nossa era (ou, inclusive, um pouco antes conforme os contextos sociais concretos), assiste-se, pelo menos em alguns âmbitos do ocidente da Península Ibérica mais afastados dos grandes centros de interacção com o mundo fenício-orientalizante, ao retorno a uma situação muito semelhante à existente antes dos contactos. Por exemplo, no vale superior do rio Nabão, o grande povoado da serra de Alvaiázere é abandonado e a sua população dispersa-se em novas localizações de menor entidade, todas com uma superfície ocupada de cerca de um hectare, menos visíveis e evidentes na paisagem, fortificadas e regularmente distribuídas pelo território, não controlando doravante bons terrenos agrícolas, mas sim as principais vias de trânsito.

Outras regiões peninsulares seguirão por caminhos diferentes, algumas decididamente na direcção do desenvolvimento e consolidação de sistemas de relações de tipo estatal, outras conservando e reproduzindo sem grandes transformações uma herança deixada por um par de séculos de exploração colonial.

Lisboa/Granada, Janeiro de 2006

\section{REFERÊNCIAS BIBLIOGRÁFICAS}

Arruda, A.M. (1999-2000). Los Fenicios en Portugal: Fenicios y mundo indígena en el centro y sur de Portugal (siglos VIII-VI a.C.). Barcelona: Universidad Pompeu Fabra de Barcelona.

Conimbriga, 45 (2006) 65-92 
BARbosa, B. (1995). Alostratigrafia e litostratigrafia das unidades continentais da Bacia Terciária do Baixo Tejo: relações com o eustatismo e a tectónica. Faculdade de Ciências de Lisboa [Dissertação de Doutoramento em Geoquímica e Sedimentologia, polic.].

Batata, C., Gaspar, F. e Batista, A. (1999). O inedetismo do $1^{\circ}$ milénio a.C. na bacia hidrográfica do rio Zêzere no contexto da arqueologia proto-histórica nacional. In Actas del II Congreso de Arqueología Peninsular (Zamora 1996). Zamora: Fundación Rei Afonso Henriques, Vol. 3, p. 25-35.

BüBner, T. (1996). A cerâmica de ornatos brunidos em Portugal. In De Ulisses a Viriato: o primeiro milénio a.C.. Lisboa: IPM/MNA, p. 66-72.

CArdoso, J.L. (1995). O Bronze Final e a Idade do Ferro na região de Lisboa: um ensaio. Conimbriga 34, p. 33-74.

CARreira, J.R. (1996a). As ocupações das Idades do Cobre e do Bronze da Lapa da Bugalheira (Torres Novas). Nova Augusta 10, p. 91-112.

CARreIRA, J.R. (1996b). Materiais da Idade do Bronze da gruta da nascente do Almonda (Torres Novas). Nova Augusta 11, p. 113-123.

Coffyn, A. (1985). Le Bronze Final Atlantique dans la Péninsule Ibérique. Paris: Diffusion de Boccard.

Coroado, J., Félix, P., Rocha, F. e Gomes, C. (2001). Caracterización química y mineralógica de cerámicas del Bronce Final en el Ribatejo Norte: primeros resultados de Quinta da Pedreira (Abrantes). In Actas del III Congreso Nacional de Arqueometría. Sevilla: Universidad de Sevilla, p. 293-300.

Coroado, J., Triães, R., Félix, P., Rocha, F. e Gomes, C. (2004). Compositional and textural characterisation of a group of pottery sherds from the Late Bronze Age settlement of Quinta da Pedreira (Abrantes, Portugal). In Acts of the XIVth UISPP Congress, University of Liège, Belgium, 2-8 September 2001. Section 2: Archaeometry. General Sessions and Posters. Oxford: British Archaeological Reports - International Series 1270, p. 61-69.

Cunha, L. (1990). As serras calcárias de Condeixa-Sicó-Alvaiázere: estudo de geomorfologia. Coimbra: INIC.

Díaz-Andreu GarcíA, M. (1994). La Edad del Bronce en la provincia de Cuenca. Cuenca: Diputación Provincial de Cuenca.

FÉlIX, P. (1997). O final da Idade do Bronze no médio Tejo. Quinta da Pedreira (Abrantes): notícia de duas campanhas de escavações arqueológicas. Al-madan 6 (Série II), p. 33-37.

FÉlIX, P. (1999). Serra de Alvaiázere: um povoado fortificado do Bronze Final no centro de Portugal. Al-madan 8 (Série II), p. 63-71.

FÉLIX, P. (2004). Un primer acercamiento al estudio del Bronce Final y Hierro Antiguo en el Ribatejo Norte (Centro de Portugal). Arqueología y Territorio 1, p. 101-118 .

FERreIRA, C.J.A. (1992). A necrópole tardo-romana e visigótica da Pedreira, Rio de Moinhos - Abrantes. Arqueologia Medieval 1, p. 91-110.

Gómez ToscAno, F. (1997). El Final de la Edad del Bronce entre el Guadiana y el Guadalquivir. Huelva. Universidad de Huelva. 
Kalb, P. e Höck, M. (1988). O povoamento pré-histórico de Alpiarça. Arqueologia 17, p. 193-200.

Marques, G. e Andrade, G.M. (1974). Aspectos da Proto-História do território português: 1. Definição e distribuição geográfica da cultura de Alpiarça (Idade do Ferro). In Actas do III Congresso Nacional de Arqueologia. Porto, Vol. I, p. 125-148 .

Pavón Soldevila, I. (1998). El tránsito del II al I milénio a.C. en las cuencas medias de los ríos Tajo y Guadiana: la Edad del Bronce. Cáceres: Universidad de Extremadura.

Pereira, I. (1993-94). Casais agrícolas da Idade do Ferro na foz do Mondego - Figueira da Foz. Conimbriga 32-33, p. 75-85.

Ponte, S. (2001). Corpus Signorum das fíbulas proto-históricas e romanas: Portugal. Faculdade de Letras da Universidade do Porto (Dissertação de Doutoramento em Arqueologia, polic.)

Reimer, P. J., Baillie, M. G. L., Bard, E., Bayliss, A., Beck, J. W., Bertrand, C. J. H., Blackwell, P. G., Buck, C. E., Burr, G. S., Cutler, K. B., Damon, P. E., Edwards, R. L., Fairbanks, R. G., Friedrich, M., Guilderson, T. P., HogG, A. G., Hughen, K. A., Kromer, B., McCormac, F. G., Manning, S. W., Ramsey, C. B., Reimer, R. W., Remmele, S., Southon, J. R., Stuiver, M., Talamo, S., TAYlor, F. W., van DER Plicht, J. e WeyhenMeyer, C. E. (2004). IntCal04: Terrestrial radiocarbon age calibration, 26-0 ka BP. Radiocarbon 46, p. 1029-1058.

Ruiz Delgado, M.M. (1989). Fíbulas protohistóricas en el sur de la Península Ibérica. Sevilla: Universidad de Sevilla.

SEnNA-Martínez, J.C. (1993). O “Grupo Baiões/Santa Luzia”: contribuições para uma tipologia da olaria. Trabalhos de Arqueologia da EAM 1, p. 93-123.

Stuiver, M. e ReIMER, P. J. (1993). Extended 14C database and revised CALIB radiocarbon calibration program. Radiocarbon 35, p. 215-230.

VAN DER LEEUW, S.E. (1984). Dust to dust: a transformational view of the ceramic cycle. In Van der Leeuw, S.E. e Pritchard, A.C., eds., The many dimensions of pottery: ceramics in archaeology and anthropology. Amsterdam: Universiteit van Amsterdam, p. 708-773.

Vasconcellos, J.L. (1917). Coisas velhas. O Arqueólogo Português 22, p. 107-169.

VILAÇA, R. (1995). Aspectos do povoamento da Beira Interior (centro e sul) nos finais da Idade do Bronze. Lisboa: IPPAR.

VilaçA, R. e ARruda, A.M. (2004). Ao longo do Tejo, do Bronze ao Ferro. Conimbriga 43, p. 11-45.

Vilaça, R., Cruz, D.J. e Gonçalves, A.A.H.B. (1999). A necrópole de Tanchoal dos Patudos (Alpiarça, Santarém). Conimbriga 38, p. 5-29. 


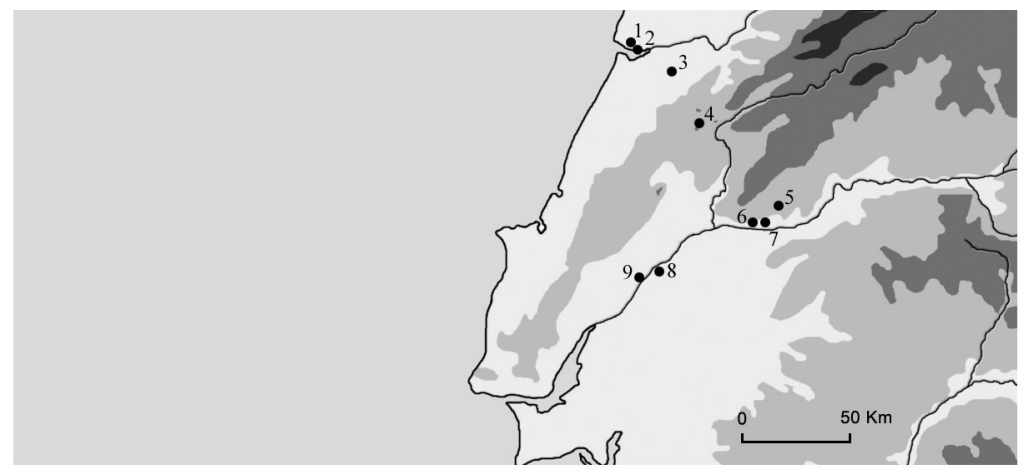

FIG. 1 - Mapa de localização de alguns dos sítios arqueológicos referidos no texto:

1. Castro de Tavarede; 2. Santa Olaia; 3. Conímbriga; 4. Serra de Alvaiázere;

5. Castelo da Cabeça das Mós; 6. Quinta da Pedreira; 7. Fortaleza de Abrantes; 8. Alto do Castelo; 9. Santarém

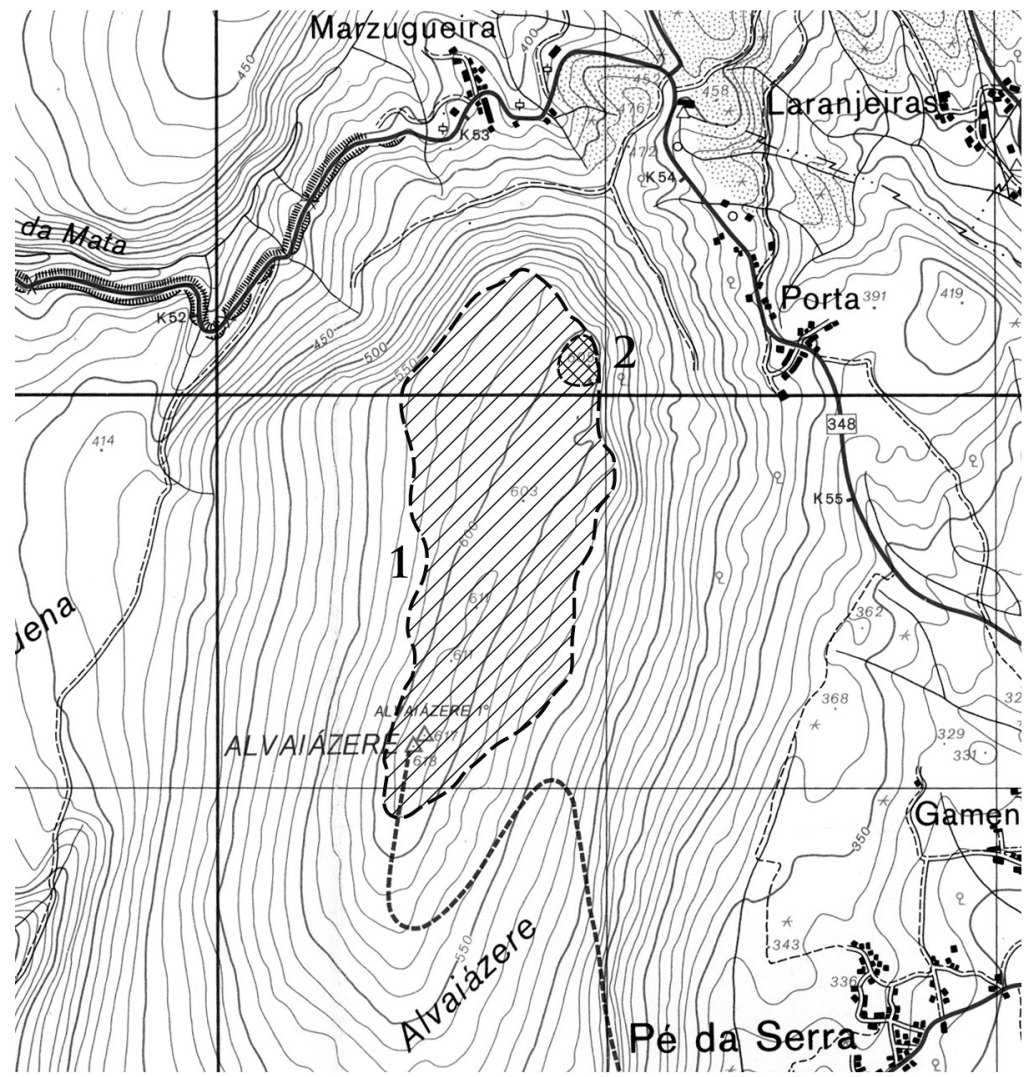

FIG. 2 - Localização do povoado fortificado de Serra de Alvaiázere na CMP 1:25000: 1. Área inscrita pela cintura exterior de fortificação; 2. Zona da "Estrutura Circular" 
EsT. II
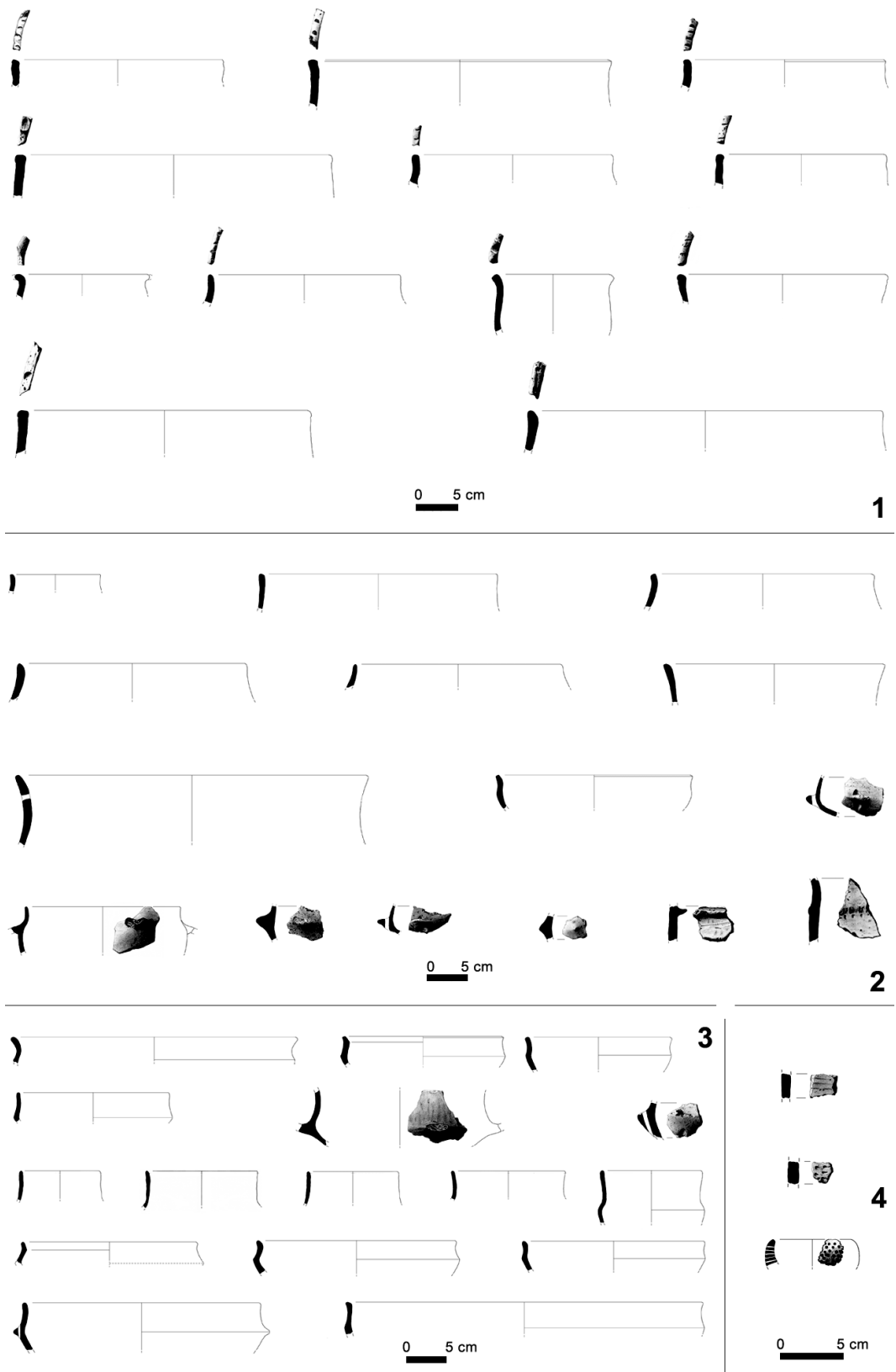

Alguns materiais cerâmicos provenientes da Serra de Alvaiázere:

1. Cerâmica com lábios decorados; 2. Cerâmica com superfícies não brunidas;

3. Cerâmica com superfícies brunidas; 4. Cerâmica decorada com sulcos brunidos, com impressões de tipo "Boquique" e "queijeira/coador" 
EsT. III

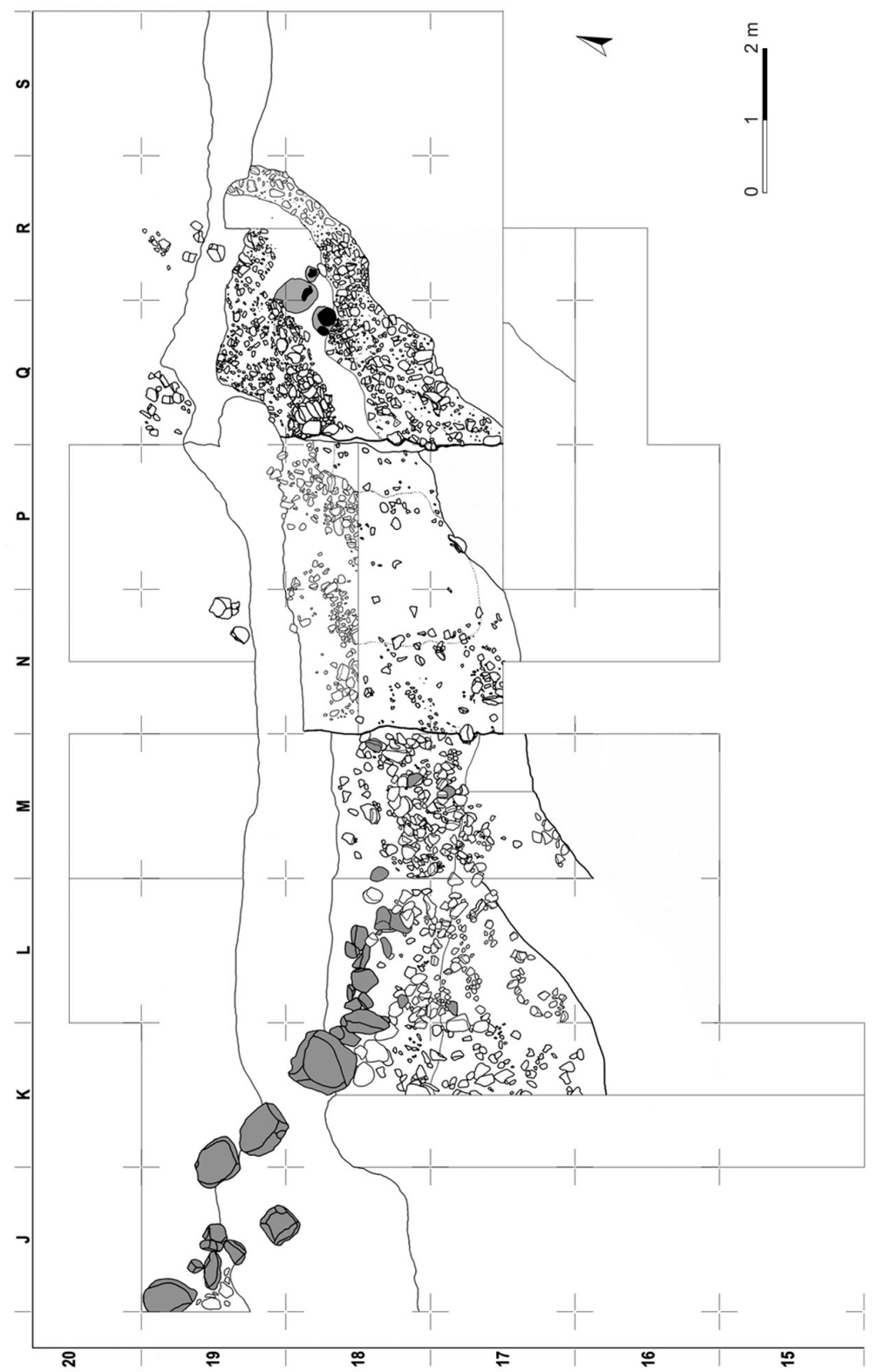

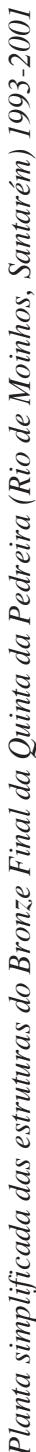


EsT. IV
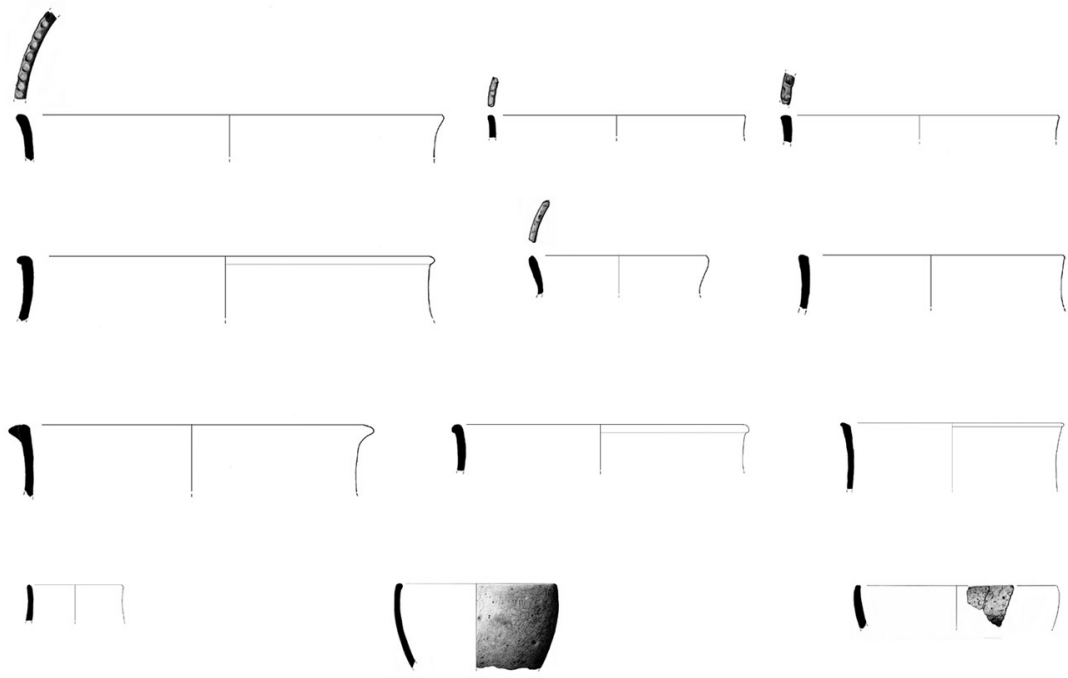

1
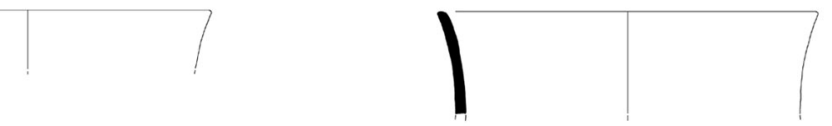

1
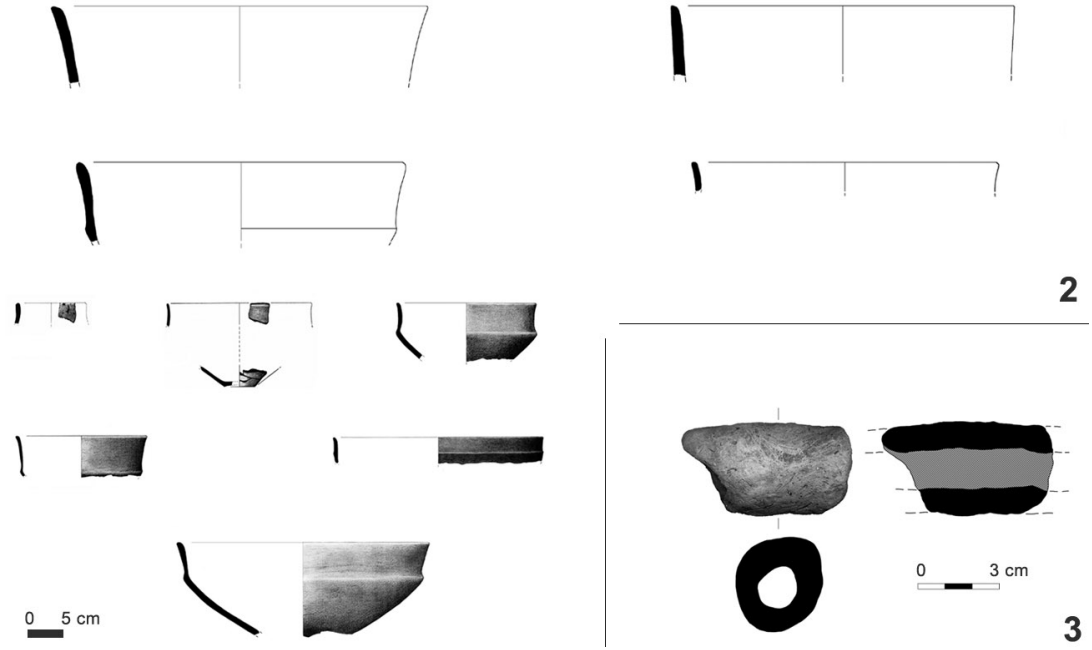

Alguns materiais provenientes da Quinta da Pedreira: 1. Cerâmica com superfícies não brunidas; 2. Cerâmica com superfícies brunidas;

3. Tubeira de forno de fundição 


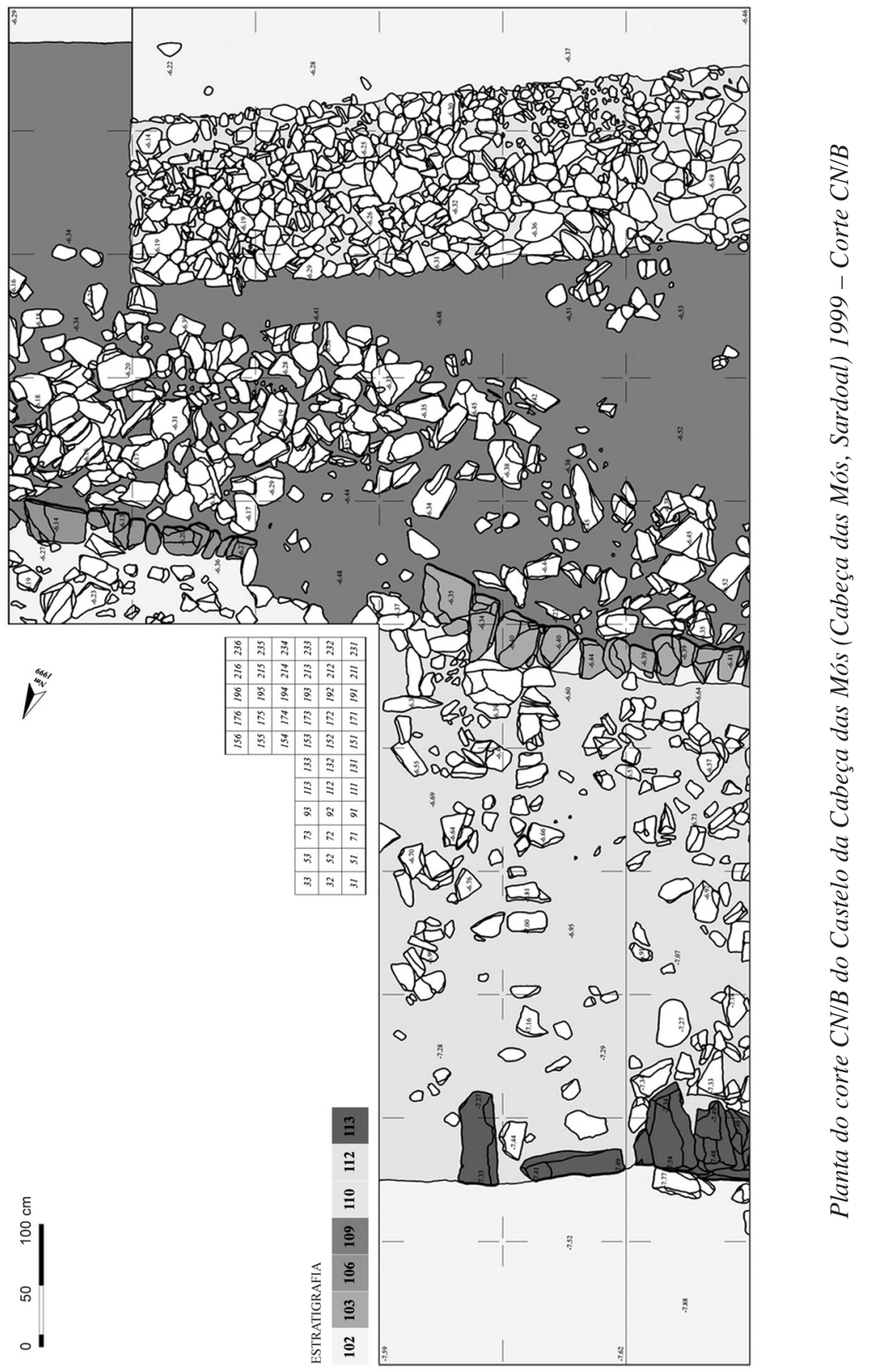



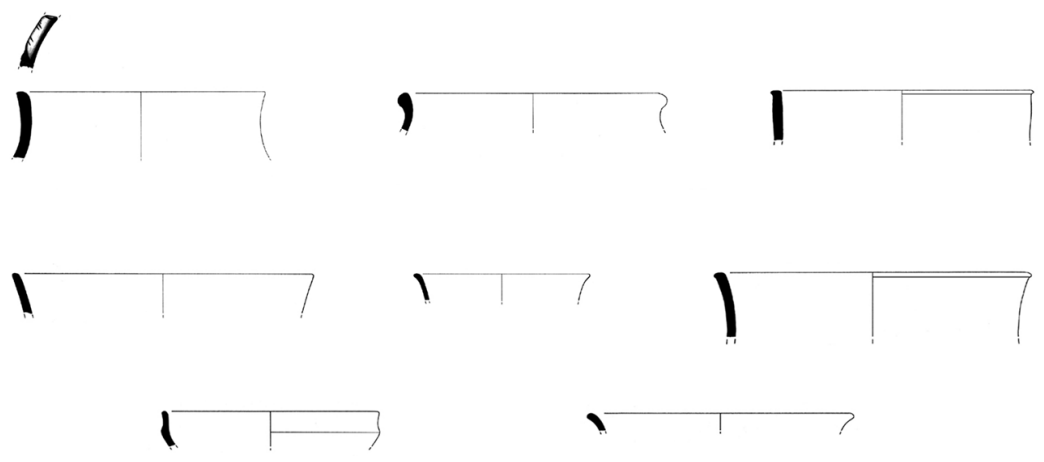

\begin{tabular}{ll}
$0 \quad 5 \mathrm{~cm}$ & 1 \\
\hline
\end{tabular}
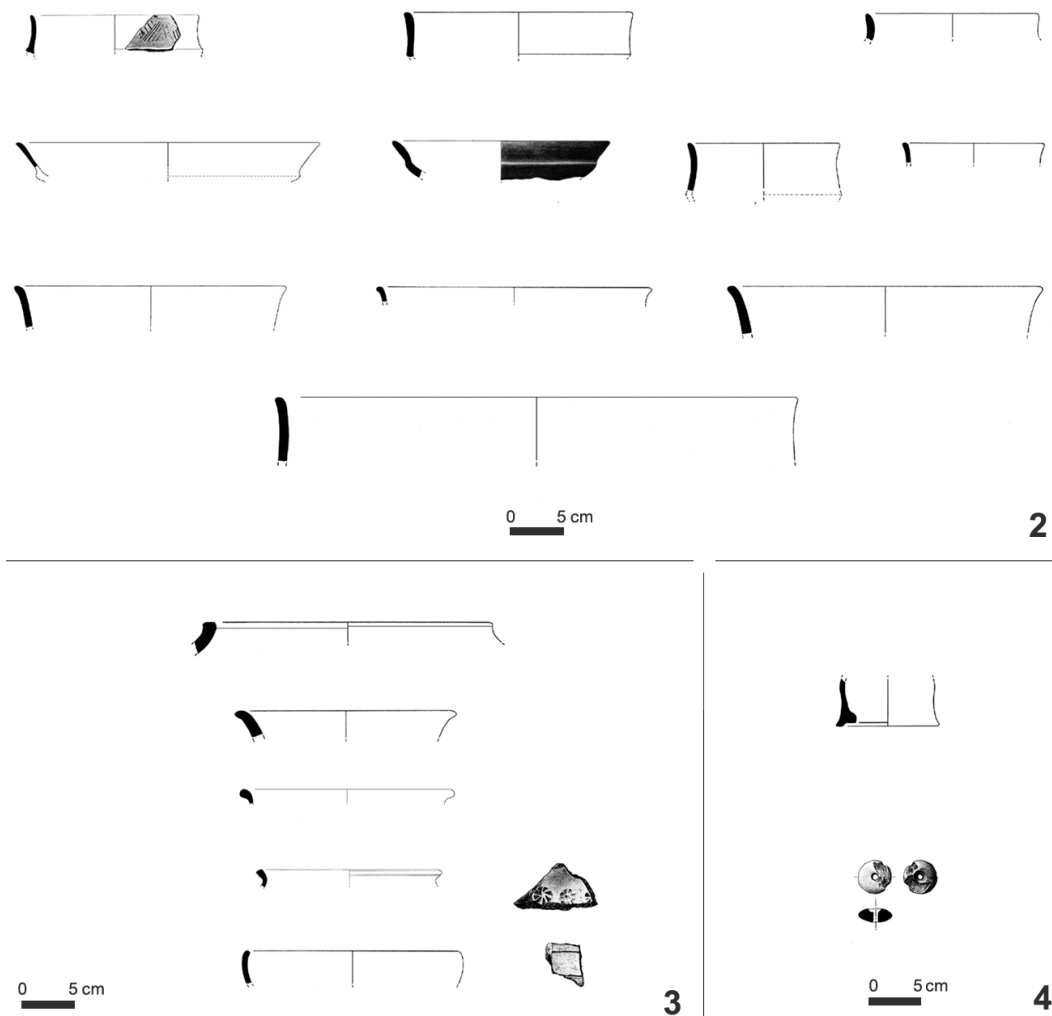

4

Alguns materiais provenientes do Castelo da Cabeça das Mós: 1. Cerâmica com superfícies não brunidas de tradição Bronze Final; 2. Cerâmica com superfícies brunidas de tradição Bronze Final; 3. Cerâmica da Idade do Ferro manual e a torno; 4. Provável chaminé de forno de fundição e fusaiola de cerâmica 